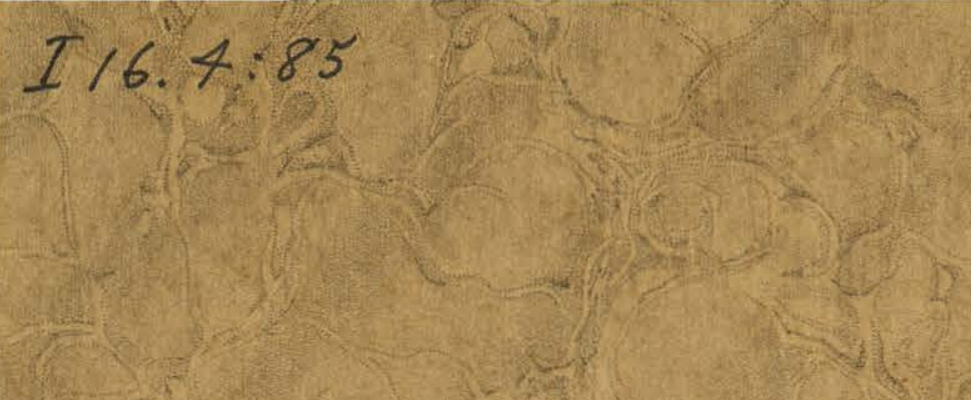

Legislative Action in 1933 Affecting Education

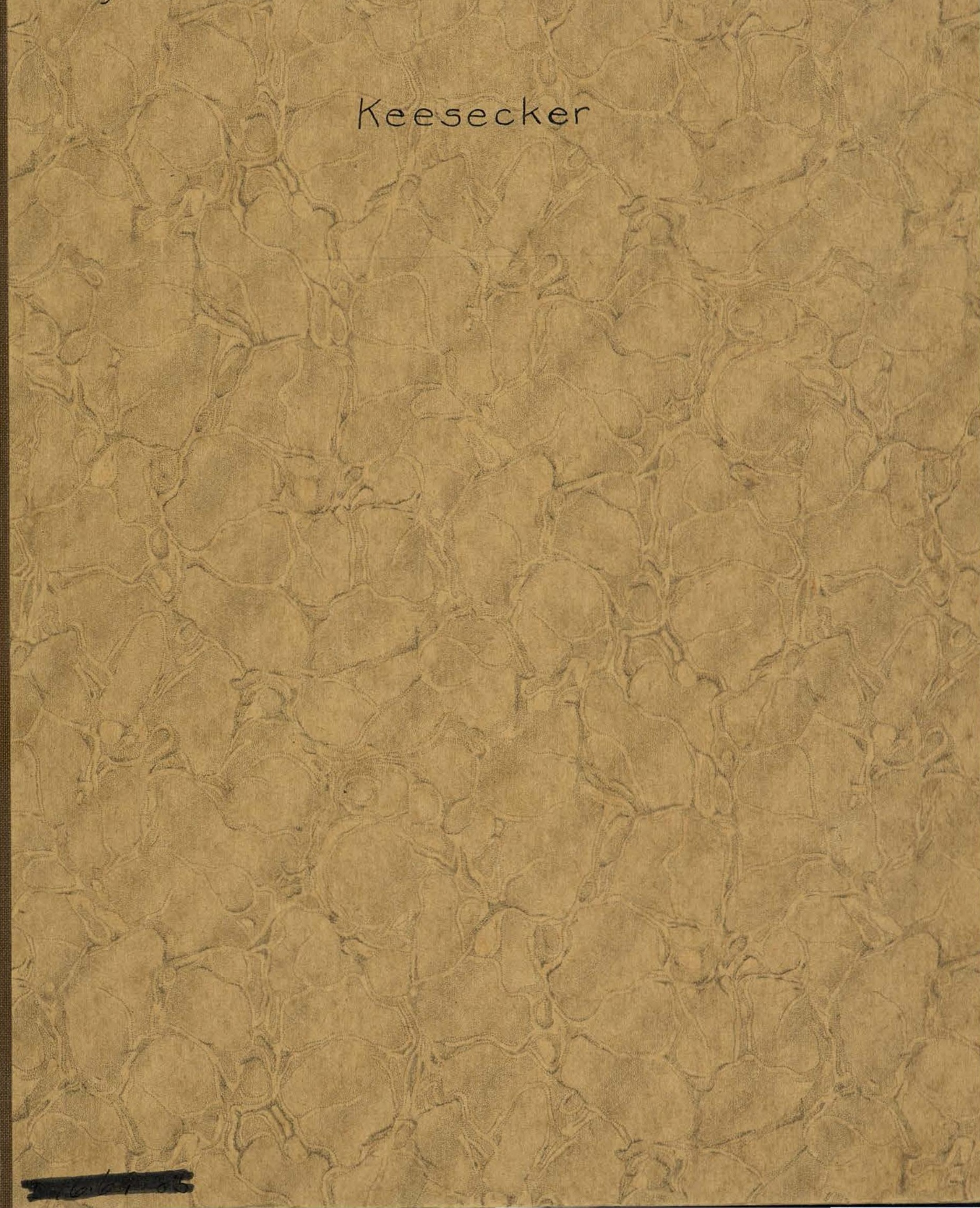





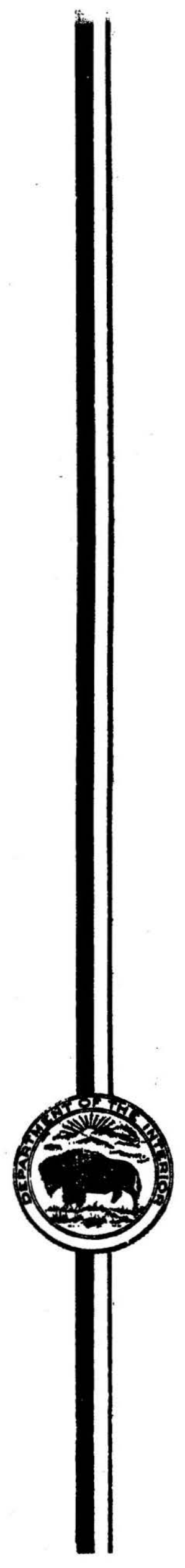

CIRCULAR NUMBER 85

Washington, D. C.

April, 1933

\section{LEGISLATIVE ACTION IN 1933}

\section{AFFECTING EDUCATION}

\section{By}

Ward W. Keesecker

Specalist in Schoöl Legislation

UNITED STATES

DEPARTMENT OF THE INTERIOR

OFFICE OF EDUCATION 

UNITED STATES

DEPARTIIENT OF THE INTERIOR

Office of Education

Washington, D. C., April, 1933.

\author{
Circular No. 85 \\ LEGISTAATIV ACTION IN 1933 AFFHCTI-NG \\ EDUCATION
}

\author{
By \\ Ward W. Keesecker \\ Specialist in School. Legislation
}

This is the first of a series of circulars to be issued during the year concerning 1933 legislative enactments and proposals afiecting education in the various States. Complete returns have not yet been received from most States and it will not be possible to give in each circular information for all states; the enactments and proposals reported should not be regarded as complete for the States under which they appear. Under "Mecsures proposed" are summaries of some bills the legislative status of which has not yet been reported to this office.

It is expected that bofore the end of the year a complete review of 1933 educational enactments will be available. 
ARIZONA

Arizona amended Section 1048 of the Revised Code of 1928 so as to provide that the State shall furnish freo textbooks for all State welfare institutions maintaining educational facilities. The secretary of the Board of Directors of State Institutions was directed to furnish a list of textbooks necessary for State welfare institutions.

\section{ARKANSAS}

The legislature abolished the office of county board of education and the office of county superintendent and provided that all porers and duties now vested in the county board of education shall be vested in the county court and all powers and duties no: vested in the county superintendent shall be vested in the county examiner. The county judge has the authority to appoint a county examiner for a two-year term subject to the approval of the county court. The county examiner is required to possess a professional teacher's license and shall remain active in the teaching profession and his salary shall not exceed $\$ 650$ per year.

A bill to abolish the State Board of Education and the office of commissioner of Education and authorize the Governor to appoint a temporary State board to select a State superintendent to serve until the next general election, when the Superintendent of Fublic Instruction shall be elected by the people, passed both houses and was submitted to the Governor.

\section{CAIIFORNIA}

\section{Measures proposed:}

Proposed constitutional amendment No. I (Senate). Would eliminate constitutional guarantees for State and county public school support and provision requiring use of State and 60 per cent of county fund for teachers' salaries.

Proposed constitutional amendment No. 2 (Senate). Would reduce minimum State support for schools from $\$ 30$ to $\$ 27$ per unit pripilf:of elementary and high school average daily attendance; and would moke levy of county, elementary and highschool taxes optional with boards of supervisors with maxirmu of $\$ 24$ and $\$ 48$ per unit of elementary and high-school average daily attendance, respectively.

S.B. 132. Would give County board of supervisors same control of school district budgets as board has over county budgets.

S.B. 167. Would make State Teachers Colleges "State Colleges;" with authority" to grant degress upon approval of the State Board of Education.

S.B. 443. Fould require payment of tuition fees of $\$ 25$ per semester at State teachers colleges by students enrolled therein. 


\section{CALIFORNIA - Contimed.}

S. B. 566. Would create State Council of Educational Planning and Coordination to study problems affecting relationships between the public school system and the University of California.

S. B. 574. Would create in eech county a local board of tax and expenditure control to control tax levies, indebtedness and expenditures of the county and political subdivisions thereof.

\section{COIORADO}

Measures proposed

S. B. 169. Would make it unlawful for any higher education institution of the State or any of its officers to expend any money in advertising such higher institution outside the State for the purpose of inducing persons to enter such educational institution.

S. B. 390. Would require tuition fees at State normal schools at Greeley, Gunnison, and Alamo'sa.

S. B. 407. Would provide a local government budget system and require local governments to present a complete financial plan for each ensuing budget year. Such a plan to include (1) an outline of the fiscal policy of the local government, describing the important features of the budget plan; (2) a general budget summary setting forth the aggregate figures of the budget, which shall be supported by explanatory schedules or statements classifying the expenditures; (3) Statement of the bonded indebtedness of the local governments.

\section{CONNEC TICUT}

Measures proposed

H. B. 60 Would make provisions for the equalization of educational opporm tunities and gurantee $\$ 70$ per pupil per average daily attendance. Would require each town in order to be eligjble for the equalization grant to raise by local tares an amount equal to 34 pen cent of the average tax income for three years preceding and spend this amount tugether with the income from local permanent school funds for current el ementary and high-school support, exclusive of expenditures under capital outlay. This bill carries an appopriation amounting to $\$ 3,105,469$ for each of the fiscal years of the ensuing biennium.

H.B. 113. Would authorize two or more towns to unite to form a high-school district for the purpose of constructing and maintaining a high-school upon such terms and conditions as shall be agreed upon by them.

H.B. 450. Would divest State Board of Education of authority to confer degrees in education.

H. B. 452. Would provide teacher tenure for all teachers appointed and employed in the public schools after at least three years of satisfactory probationary service. 


\section{DHE.AW ARE}

\section{Measures proposed}

H.B. 68. Would pay all of the maturing bonds and all the interest thereon for each district for the biennium. (Reported favorably.)

H.B. 103. Would prohibit the appointment of any principal, superintendent or teacher unless he has one year's residence, which means that he or his parents must be registered voters and have a home in Delaware at least nine months in the year.

H. B. 344. Fould prohibit the State Board of Education from employing any person to act in any capacity of supervisor of public schools. ("Apparently this would keep any representative of the state Department from going into any schoolroom as a supervisor.")

H. B. 345. Would provide that no person shall be employed to teach art, music, or athletics.

S.B. 28. Hould provide for a survey of the State school system and appropriate $\$ 10,000$ therefor.

S.B. 30. Would allow the State board to close a one-room school which has had less than 20 pupils in average daily attendance for two years.

\section{IDAHO}

The legislature reduced appropriations to all educational institutiona from 20 per cent to 39 per cent of the amount appropriated for the last biennium. It provided for a tax on chain stores ranging from $\$ 5$ for one store to $\$ 500$ for 20 or mòre stores. (It is estimated that this will provide from $\$ 50,000$ to $\$ 250,000$ for the school equalization fund.)

A school equalization law was enacted. This law provides that a three-mill district levy and State and county apportionments shall provide $\$ 120$ per month per classroom unit and $\$ 160$ per month per high-school classroom unit. It also provides that if the district levy of three mills does not provide the minimum requirement above stated, the county and State apportionments must provide the balance. County levies, therefore, must be sufficient when State money evailable is added to their proceeds to provide this amount for each district.

Furthermore, the legislature abolished the office of Commissioner of Education and transferred the duties of that office to the office of the State superintendent. The salary of the State Superintendent was increased from $\$ 2,400$ to $\$ 3,600$ per annum.

The legislature also provided three plans under which school districts may consolidate and provided that two or more districts may combine their schools for educational purposes without consolidation. 
IDAHO - Continued.

\section{Measures proposed.}

H.J.R. 3. Would provide a constitutional amendment for the elimination of the elective office of State superintendent." (Passed the House.).

H.B. 116. Would provide for the election of a nonpartisan State Board of Education on a nonpartisan ballot.

S.B. 50. Would provide for a county board to control all budgets of all dism. tricts, including school districts.

S.B. 62. Would provide a penalty for any board of trustees or other school officers who make or request a teacher to divulge anything about his religious affiliations. (Defeated in the Senate.) (..........

\section{INDIANA}

The legislature extended the general salary reduction act of 1932 for two years and provided that the minimum salary shall not be less than $\$ 800$ per school year for elementary teachers and $\$ 1,000$ for high-school teachers.

A State tax was imposed on intangible property: 10 per cent of which is paid into the general fund of the State and of the remaining 90 per cent one-fourth is paid into the county general fund and. three-fourths to the school corporations of the county.

A 7-cent property tax and a 50-cent poll tax are levied for a common school relief fund, which may be used to pay the approved and allowed deficit on the cur rent operating expenditures of the school relief claims of such poorer school comporations as comply with the eligibility qualifications as may be set up by the State Board or the Department of Bducation. Furthermore, the State was authorized to reimburse each employing corporation $\$ 600$ per teacher per anmum on the basis of one teacher for each 35 pupils or major fraction thereof. in average daily. attendance in grades 1 to 8 and one teacher for each 25 pupils or major fraction thereof in average daily attendance in grades 9 to 12.

$$
\text { IOFA }
$$

Measures proposed

H. B. 3\% Would establish uniform financial system in public schools. (Passed both houses.)

H. B. 39. Would allow centralized school purchasing.

H. B. 42. Would make kindergarten optional instead of mandatory. (Enacted int. law.) 


\section{IOWA-Continued.}

Measures proposed - Contimed.

H.B. 295. Would eliminate State inspectors and require county superintendents of schools to make anmul inspection of all schools in their counties.

H.B. 317. Would make military training in State educational institutions optional with students.

S.B. 195. Would repeal most of the laws covering the certification of teachers and would substitute provisions calling for the issuance of four classes of regular certificates based upon collegiate work. This act would abolish the prom visions for certificates by examination.

S.B. 335. Would permit school boards to supply free, lend, rent, or sell school books to pupils.

\section{MAINE}

The legislature provided for a State commission of 15 representative citizens to be appointed by the Governor to study public-school finances. The commission is directed to make a special study of equalized valuation, more equitable sources of revemue and the distribution of State funds on an "equalized mathematical basis and shall employ such expert counsel as in its judgment may seem advisable.

The legislature made a reduction in the school budget for the ensuing biennium in the amount of about $\$ 250,000$ per annum.

\section{NESW MEXICO}

The legislature provided for the eatablishment of a State public school equalization fund and for its distribution among the various counties of the state upon a per capita basis. Each county, regardless of assessed valuation, length. of school terr, or population, shall share proportionately in such funds as its average daily attendance bears to the total of average daily attendance of all public schools of the State. "The purpose of this act being to relieve and decrease property taxes. . ." (H. B. 353)

Imposed an excise tax of 4 cents per gallon upon the use of all lubricating oil, the proceeds of which shall be paid into the State treasury and used for the furnishing of free textbooks to school children. (H.B. 79)

Abolished all county boards of education and created a school district which shall be known as the "Rural-schools of County, New Mexico," which shall be composed of those school districts not a part or an annex of municipal or rural independent school districts. The new boards of education created shall be composed of 5 members elected for 6 -year terms with substantially the same powers now possessed by. boards of education in mumicipal districts. (H.B. I72) 
71142.

NEW MEXICO - Continued.

Provided for the establishment of a State-wide retirenent system for teachers employed in the public schools and other educational institutions supported by the State. (S.B. 224)

\section{NORTH CAROLINA}

The legislature provided that the tax reduction fund as set up and provided for by Chapters 429 and 440 of the 1931 laws for aiding counties and school districts to maintain schools longer than six-nonth tern shall not be reduced by the Director of the Budget by a greater percentage than the average percentage reduction of all other appropriations. It was also provided that the state shall pay one-half of the cost of the extended school term irresoective of the amount of ad-valoren tax actually collected in the respective counties and districts.

\section{OREGON}

The legislature invalidated the teachers mininum salary law for a two-year period; made amendments to the county-unit law, which is now nodeled after the Utah courty-unit system; transferred the administration of vocational rehabilitation from the State Industrial Accident Comission to the State Board for Vocational Education; created an educational cormission composed of seven citizens appointed by the Governor to study the public elementary and high-school systems with special reference to organization and finance.

\section{RHODE ISIAAND}

The House of Representatives passed a bill (H. 367) which created a comrittee composed of 6 menbers of the House to investigate the activities of certain students of "Brown University in pledging tineir fellow students not to bear arms except in case of invasion of the mainland of the United States, and all activities connected with the so-called 'pacifist movenent' in any institution in this State aided by public funds, and to report to this body as soon as nay be recomendations for appropriate legislation to prevent tine use for disloyal purposes of buildings or facilities of any institution aided or supported by public funds, and to provide appropriate penalties for disloyalty toward the State of Rhode Island or the United. States."

\section{WYOMING}

The legislature provided for the distribution of the Government royalty fund for six months term instead of eight months (this fund is derived from mineral leases on federal lands); allowed earlier distribution of county funds, thus cutting down interest; revised the nomal training laws by eliminating certain tax levies and provided for supervision by State Board of Education; and enlarged the powers of school boards to provide transportation or maintenance to enable pupils to attend scinools in another district (linits the anount for this purpose to $\$ 10$ per month per child in certain cases). 




